\title{
Stimulation of extracellular invertase production from spent yeast when sugarcane pressmud used as substrate through solid state fermentation
}

\author{
Rahul Kumar and Balakrishnan Kesavapillai
}

\begin{abstract}
Efforts were made to utilize the waste/by-product of two agro-process industries namely pressmud from sugar processing industries and spent yeast from distilleries manufacturing ethanol from cane molasses, for the production of microbial invertase. Our experimentation indicated that these two sources could be ideally utilized for the production of invertase through solid substrate fermentation (SSF). SSF with spent yeast had given highest specific activity of $430 \mathrm{U} / \mathrm{mg}$ in $72 \mathrm{~h}$ of fermentation. Inoculum percentage of yeast cells on pressmud was optimized as 50\% (w/W) with a combination inoculum of spent yeast and fresh cultured yeast at a ratio of 7:3. Crude enzyme was characterized for optimum pH and temperature and maximum activity was recorded at pH 5.0 and at a temperature of $40^{\circ} \mathrm{C}$. Impacts of metal ions and detergents on invertase action were studied in which $\mathrm{Mn}^{2+}, \mathrm{Fe}^{3+}, \mathrm{Al}^{3+}$ and detergents had enhanced the activity of the enzyme whereas $\mathrm{Cu}^{2+}$ and $\mathrm{Zn}^{2+}$ inhibited the enzyme activity. Purification of 9.8 folds was obtained by using three phase partition method.
\end{abstract}

Keywords: Invertase, Pressmud, Spent yeast, SSF, Crude invertase characterization

\section{Background}

Invertase or $\beta$-fructofuranosidase (EC 3.2.1.26) resulting in the production of invert sugar which has a lower crystallinity than sucrose at high concentrations, finds numerous applications in the food industry. Confectionary's preference for invert sugar hovers around its ability to keep the products fresh and soft for prolonged periods. Soluble invertase is used in the sweet industry for the production of artificial honey. Enzyme catalysed hydrolysis has the advantage of colourless products compared to the coloured version obtained through acid hydrolysis (Arica et al., 2000; Bayramoglu et al., 2003).

Invertase occurs widely in nature and its presence has been reported in plants, certain animal tissues and microorganisms. There are several reports available inliterature for the purification of invertase from different sources employing various traditional purification processes (Liu et al., 2006; Guimaraes et al., 2009; Jegou et al., 2009; Hussain et al., 2009; Nguyen et al., 2005).

\footnotetext{
* Correspondence: rainbalu@gmail.com

Technology Business Incubator (TBI), Bannari Amman Institute of Technology, Sathyamangalam 638 401, India
}

Studies have been carried out by using synthetic medium for preparation of invertase while a little attention has been paid on its production from un-conventional inexpensive sources (Vitolo et al., 1995; Ashokkumar et al., 2001; Rashad et al., 2006; Guimaraes et al., 2007; Guimaraes et al., 2009). Also, the production of enzymes by solid state fermentation (SSF) have potential advantages over submerged fermentation $(\mathrm{SmF})$ with respect to uncomplicatedness in operation, high productivity fermentation, less favorable conditions for growth of contaminants and concentrated product formation (Ashokkumar et al., 2001).

Growing concern about pollution that occurs from agricultural and industrial wastes has motivated curiosity in converting waste materials into commercially valuable products. The agro-food industry produces large volumes of wastes, both solids and liquids resulting from the production, preparation and consumption of food. Besides their pollution and hazardous aspects, in many cases, food processing wastes might have potential for recycling raw materials or for conversion into useful product of higher value (Sangeetha et al., 2005; Mamma 
Table 1 Production of invertase by SSF with different components

\begin{tabular}{|c|c|c|c|c|c|}
\hline \multirow[b]{2}{*}{ Tray No. } & \multirow[b]{2}{*}{ Sample } & \multicolumn{4}{|c|}{ Specific activity (U/mg) } \\
\hline & & $24 \mathrm{hrs}$. & $48 \mathrm{hrs}$. & 72 hrs. & 96 hrs. \\
\hline 1 & Control & 48 & 47 & 46 & 43 \\
\hline 2 & 10\% Spent yeast & 168 & 288 & 373 & 297 \\
\hline 3 & $10 \%$ Culture yeast & 210 & 223 & 267 & 240 \\
\hline 4 & $5 \%$ Spent yeast $+5 \%$ culture yeast & 192 & 283 & 275 & 260 \\
\hline 5 & Same as $3^{\text {rd }}$ tray with $2 \%$ sugarcane juice spray at every $12 \mathrm{~h}$ & 130 & 186 & 234 & 318 \\
\hline
\end{tabular}

et al., 2008; Rashad and Nooman 2008 and Guimaraes et al., 2009).

Under these circumstances it was thought that it would be ideal to scout for desirable sources exhibiting favorable levels of invertase action suitable for commercial exploitation. So the present study deals with the production, partial purification and characterization of one of the useful industrial enzymes (invertase) by utilization of some agro-processing wastes such as sugarcane pressmud and distillery spent yeast. Though there could be more costly, sophisticated and unpredictable solution to arrive at, we presume our methodology of hitting upon a system with untapped residual invertase activity could be the less costly, stable alternative which can be successfully exploited commercially.

\section{Results and discussion}

Solid state fermentation

\section{Optimization of composition of different constituents}

\section{for SSF}

Optimization of SSF for invertase activity using pressmud was attempted in these studies. Tray no 2 holding $10 \%$ spent yeast and nutrient mix added to pressmud, had shown higher specific enzyme activity $(373.2 \mathrm{U} / \mathrm{mg}$ at $72 \mathrm{~h}$; Table 1). There is a preferred release of more invertase with spent yeast samples in the pressmud milieu compared to the cultured yeast (Table 1). The membrane changes that would have taken place when present in the ethanol rich medium for prolonged periods and such stress filled ethanol production milieu would have made the spent yeast cells more susceptible to the stimulation from the SSF culturing on pressmud. There are reports of enzymes getting released from microbial cultures (when grown on solid substrates) as extracellular enzymes which otherwise were intra cellular when grown in liquid cultures (Lekha and Lonsane 1994; Mitchell and Lonsane 1992). Lonsane and Ghildyal (1992) reported this sort of stimulated release with glucose oxidase and invertase earlier.
Culture yeast with spraying of sugarcane juice (tray 5) at intervals of $12 \mathrm{~h}$ had given increase in specific enzyme activity continuously (Table 1 ) till $96 \mathrm{~h}$. It may be due to adaptability of the culture yeast to steadily start producing invertase in the presence of additional sugar in the spray liquid. Aranda et al. (2006) reported that an increase in invertase production noticed when glucose was present in the medium (up to $100 \mathrm{~g} / \mathrm{L}$ ) by Aspergillus niger in SSF.It is also suggesting the possibility that Tray 5 (Table 1) gave higher invertase activity at only $96 \mathrm{~h}$ owing to the possibility of yeast cells opting to consume reducing sugar available along with sucrose in the sugarcane juice which was sprayed onto the SSF tray intermittently.

\section{Optimization of time of harvest for SSF}

Fermentation harvest time (72 h) was optimized in SSF with $10 \%$ spent yeast as inoculum. A specific enzyme activity of $430 \mathrm{U} / \mathrm{mg}$ was reported at the end of $72 \mathrm{~h}$ of cultivation (Table 2). Alegre et al. (2009) have also reported $72 \mathrm{~h}$ as the optimum time for the production of extracellularinvertase at $30^{\circ} \mathrm{C}$ by Aspergillus caespitosus. Similar incubation period (3 days) for both intra and extracellular A. niger invertase was reported by Sirisansaneeyakul et al. (2000), Ashokkumar et al. (2001) and Mamma et al. (2008), found that the highest invertase activity produced by $A$. niger cultivated on dry orange peels was $72.5 \mathrm{U} / \mathrm{g}$ drysubstrate at $72 \mathrm{~h}$, while the highest activity produce by $N$. crassa was $74.0 \mathrm{U} / \mathrm{g}$ dry substrate under the same conditions. Rashad and Nooman (2009) had found out the highest productivity of invertase was $272.5 \mathrm{U} / \mathrm{g}$ dry substrate in $96 \mathrm{~h}$ in red carrot residue by SSF using Saccharomyses cerevisiae. Similar behaviour was reported for extracellular invertase production from $A$. niger (Park and Pastores 2003), from S. cerevisiae (Rashad et al., 2006) and from A. flavus (Uma et al., 2010). The enhancement in peak invertase activity reported in Table 2 when compared with that in Table 1 is due to the open tray cultivation adapted as SSF for the experimentation dealt in Table 1

Table 2 Optimization of duration for SSF

\begin{tabular}{|c|c|c|c|c|c|c|c|c|}
\hline Time (hrs.) & 12 & 24 & 36 & 48 & 60 & 72 & 84 & 96 \\
\hline $\begin{array}{l}\text { Specific invertase activity detected in } \\
\text { Pressmud }+10 \% \text { Spent yeast system }(\mathrm{U} / \mathrm{mg})\end{array}$ & 67.1 & 146.3 & 227.3 & 295.4 & 390.9 & 430.8 & 255.8 & 86.2 \\
\hline
\end{tabular}


Table 3 Optimization of inoculum percentage for SSF

\begin{tabular}{|c|c|c|c|c|c|c|c|c|c|c|}
\hline Inoculum\% (Spent yeast) & 10 & 20 & 30 & 40 & 50 & 60 & 70 & 80 & 90 & 100 \\
\hline Specific activity (U/mg) & 298.6 & 312.7 & 349.1 & 368.6 & 395.2 & 381.7 & 322.8 & 242.1 & 267.3 & 272.9 \\
\hline
\end{tabular}

and contained atmosphere tray SSF (tray covered with poly bag) with provision of passive gas exchange for the experiment dealt in Table 2. This means less of other organisms intimidating with SSF in the contained culturing. The specific activity at $96 \mathrm{~h}$ was low (Table 2) which could be due to accumulation of heat during exothermic activity in poly bag contained fermentation.

\section{Optimization of \% inoculum for SSF}

Inoculum percentage in SSF was optimized as $50 \%$ (w/w; i.e. $50 \mathrm{~g}$ of spent yeast pellet added to $100 \mathrm{~g}$ of pressmud with nutrient mix and water added remain the same as in other trays with varied levels of spent yeast used as inoculum) with specific enzyme activity of $395.2 \mathrm{U} / \mathrm{mg}$. When there are still enhanced levels of inoculum, contamination with fungus was noticed (Table 3). Increasing the percentage inoculum of washed spent yeast cells on pressmud gave enhanced levels of invertase till 50\% (w/w) inoculum. Beyond this level, the trend was reversed and invariably there was fungal growth observed in the plates. This may be due to the dead yeast being used as substrate by the fungus present in the unsterilized pressmud and due to less promising growth rate and activity spectrum of introduced yeast cells whenin excess, due to contact inhibition of cells. Humidity enhancement in the microenvironment also would have favoured fungal contaminations at higher levels of inoculum added.

\section{Optimization of inoculums composition i.e. ratio of Spent yeast and culture yeast}

Different composition of inoculum also influenced the yield of enzyme and hence the enzyme activity. The ratio (7:3) of spent yeast and culture yeast had given high specific enzyme activity of $297.3 \mathrm{U} / \mathrm{mg}$ for the total $20 \%$ inoculum (Table 4).

\section{Characterization of crude invertase}

\section{Optimum $\mathrm{pH}$ determination and optimum temperature}

\section{determination}

Crude invertase extracted from pressmud combinations was found possessing an optimum pH of 5.0 (Figure 1). The optimum temperature obtained for the crude enzyme activity was $40^{\circ} \mathrm{C}$ (Figure 2). Sanjay and Sugunan (2006) reported maximum activity at pH 5 and at $50^{\circ} \mathrm{C}$.
Andjelkovic et al. (2010) reported as 3.5- 5.0 the optimum $\mathrm{pH}$. The optimum $\mathrm{pH}$ from 3.5 to 7.0 hasbeen reported for invertases isolated from different yeasts (Belcarz et al., 2002; Persike et al., 2002). Andjelkovic et al. (2010) reported as $60^{\circ} \mathrm{C}$ as optimum temperature of invertase action. In general, invertases show high activity in the temperature range of $35-75^{\circ} \mathrm{C}$ depending to their sources andalso incubation time (Persike et al., 2002; Kern et al., 1992). Nguyen et al. (2005) reported the optimum temperature of $A$. niger invertase as $50^{\circ} \mathrm{C}$. Higher values of optimum invertase temperatureswere reported by many authors (Rubio et al., 2002; Guimaraes et al., 2007; Hussain et al., 2009), while lower value $\left(30^{\circ} \mathrm{C}\right)$ was reported by (Rashad et al. 2006).

\section{Impacts of metal ions and detergents}

Enhancement of crude invertase activity was observed with $\mathrm{Mn}^{+2}$ and $\mathrm{Fe}^{+3} \cdot \mathrm{Cu}^{+2}$ showed inhibitory effects for the crude invertase enzyme activity. Small increase in the activity was observed with detergents also (Figure 3). (Dahot \& Noomrio 1996) reported increase in invertase I and II activities in the presence of $\mathrm{MnCl}_{2}, \mathrm{CoCl}_{2}$ and $\mathrm{CaCl}_{2}$ but the same completelyinhibited with EDTA due to chelation with metal ions. Rashad and Nooman (2009) indicated that the enzyme was completely inhibited by $\mathrm{Hg}^{2+}$ at low concentration $(1 \mathrm{mM})$, while it was slightly inhibited by $\mathrm{Ba}^{2+}, \mathrm{Zn}^{2+}$, and $\mathrm{Fe}^{2+}$ at the same concentration. On the other hand, a slight increase inthe enzyme activity was noticed by using $1 \mathrm{mM}$ of $\mathrm{Co}^{2+}$. The inhibition of invertase by $\mathrm{Hg}^{2+}$ was reported by many authors (Guimaraes et al., 2009; Rashad et al., 2006; 2001) and they suggested that thiolgroups at the catalytic site are important for the invertase activity. Stimulation of invertase activity by $\mathrm{Co}^{2+}$ wasalso reported by Rubio et al. (2002) and Rashad et al. (2006), while (Nguyen et al. 2005) found that the enzyme was slightly inhibited by addition of $1 \mathrm{mM} \mathrm{Co}^{2+}$.

\section{Purification of crude invertase by Three Phase Partition method (TPP)}

The overall purification of invertase from culture yeast was done by TPP which gave 9.8 fold of purification for aqueous phase with specific enzyme activity of $3388 \mathrm{U} / \mathrm{mg}$ (Table 5). Our findings on the suitability of TPP method

Table 4 Optimization of inoculums composition i.e. ratio of Spent yeast and culture yeast

\begin{tabular}{llllll}
\hline $\begin{array}{l}\text { Spent yeast : Culture yeast (together they } \\
\text { constituted } \mathbf{2 0} \% \text { (w/w) of pressmud }\end{array}$ & $1: 9$ & $3: 7$ & $5: 5$ & $\mathbf{7 : 3}$ & $9: 1$ \\
\hline Specific activity (U/mg) & 147.3 & 192.7 & 247.5 & $\mathbf{2 9 7 . 3}$ & 289.7 \\
\hline
\end{tabular}




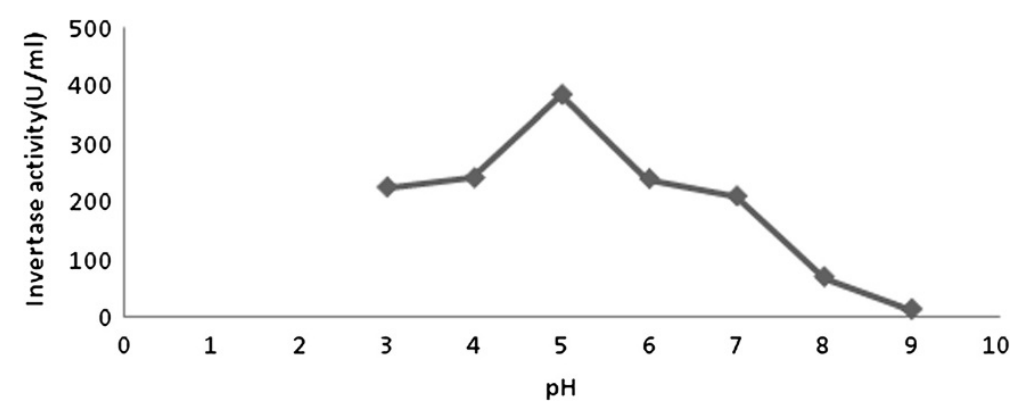

Figure 1 The effect of optimum pH (5.0) on the activity of invertase.

for the purification of invertase was supported by a number of findings. Akardere et al. (2010) had found 15 fold of purification for aqueous phase from Baker's yeast by TPP method. Ozer et al. (2010) had found 8.6 fold of purification for interfacial phase from tomato by TPP method. A TPP process was reported as giving purification folds of 9 for the interphase of tomato pectinase (Sharma and Gupta 2001).

\section{Conclusions}

The present study though confirmed the presence of invertase enzyme activity in fresh Pressmud and spent yeast, residual specific invertase activity from spent yeast when cultured on fresh pressmud was found to be higher in titers. Solid state fermentation triggered on press mud as substrate gave maximum specific activity at $72 \mathrm{~h}$ of spent yeast cultivation. Combination of spent yeast \& fresh cultured yeast (7:3) as inoculum gave maximum invertase activity at $72 \mathrm{~h}$. Till $50 \% \mathrm{w} / \mathrm{w}$ of spent yeast on pressmud favored maximum invertase production. The crude enzyme activity was optimized in terms of temperature and $\mathrm{pH}$. Impact studies for the metal ions showed fair increase in the residual enzyme activity in presence of metal ions and marginal increase by detergents. About 10 folds of purification of crude enzyme activity obtained by means of three phase partition method.

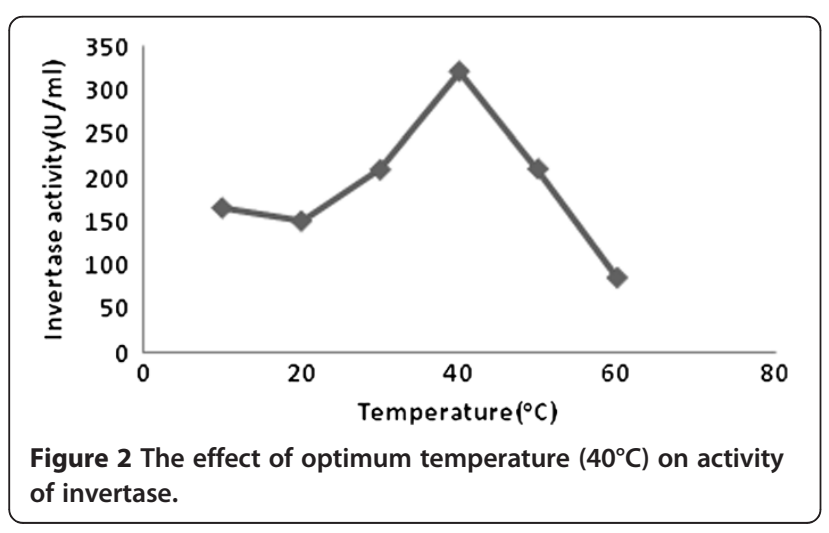

\section{Methods}

\section{Microorganisms}

Spent yeast samples (yeast cell slurry deposited at the bottom of ethanol fermentation tanks inoculated with Sachharomyces cereviceae) were provided by Bannari Amman Distilleries, Modur, and Erode. The slurry collected was centrifuged at lab level (6000 rpm for $10 \mathrm{~min}$ ) and the resultant cell pellet was washed twice with water to discard chemical residues settled along with cells. This washed spent yeast cells were introduced to pressmud at $10 \%(\mathrm{w} / \mathrm{w})$ (if there was variation in inoculum percentage, the same was specifically mentioned) as inoculum.

A local isolate of S. cereviceae maintained in YDP slants was used as fresh cultured yeast (2 loops of the yeast transferred to $50 \mathrm{~mL}$ of YDP broth held in $250 \mathrm{~mL}$ conical flask and incubated at $120 \mathrm{rpm}$ for $24 \mathrm{~h}$ ) wherever added as part of the inoculum. This culture was maintained as glycerol stock in glycerol: water $(1: 1) \mathrm{mix}$ at $-20^{\circ} \mathrm{C}$. Sub cultures were made by streaking on to YDP agar.

\section{Solid state fermentation (SSF) of sugarcane pressmud Optimization of composition of different constituents for SSF}

Fresh pressmud (100 g each) was taken in five different sterilized stainless steel plates $(30 \times 20 \mathrm{~cm})$ and different compositions of constituents were added to carryout SSF in open (as in experiment dealt in Table 01)/closed

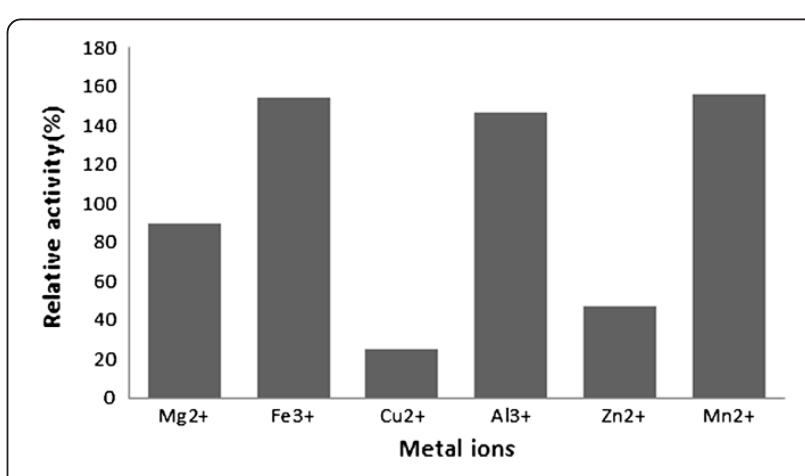

Figure 3 The effect of metal ions $(5 \mathrm{mM})$ on activity of invertase. 
Table 5 Summary of overall purification of invertase by three-phase partitioning

\begin{tabular}{lcccc}
\hline Steps & Total activity (Unit) & Total protein $(\mathbf{m g} / \mathbf{1 0 0} \mathbf{~ m l})$ & Specific activity(U/mg) & Purification fold \\
\hline Crude extract & 165 & 48 & 344 & 1 \\
TPP-aqueous phase & 62 & 1.83 & 3388 & 9.85 \\
\hline
\end{tabular}

and contained environment with a controlled temperature and humidity of $30^{\circ} \mathrm{C} ; 94 \%$ respectively. In tray number one (un-inoculated plate, pressmud was mixed with nutrient mix containing sucrose (1\%), ammonium sulphate $(0.4 \%)$ and peptone $(0.2 \%)$ dissolved in $25 \mathrm{~mL}$ of tap water. The composition of media constituents in various trays was depicted below (Table 6). The contents of the plates were mixed well and kept for solid state fermentation for a period of $96 \mathrm{~h}$. Humidity (90-95\%) was maintained by manually spraying of sterile distilled water in every $12 \mathrm{~h}$. Sample (20 g) were collected at every $12 \mathrm{~h}$ andfermented solid was mixed with the $80 \mathrm{ml}$ of extraction buffer (100 mM Potassium phosphate, $10 \mathrm{mM} \beta$ mercaptoethanol and $1 \mathrm{mM}$ phenyl methyl sulfonyl fluoride) and kept for stirring for $30 \mathrm{~min}$ at $10^{\circ} \mathrm{C}$. Leachate was filtered with nylon cloth and centrifuged at $6000 \mathrm{rpm}$ for $15 \mathrm{~min}$ at $10^{\circ} \mathrm{C}$. Supernatant was used as crude invertase and went for invertase assay.

\section{Optimization of duration of fermentation time}

In $100 \mathrm{~g}$ of fresh pressmud, $10 \%$ of spent yeast $(\mathrm{w} / \mathrm{w})$ mixed with nutrient mix in $25 \mathrm{ml}$ of tap water was added. They were mixed well and spread like a bed on a stainless steel tray and kept for solid state fermentation for 96 h. Humidity (90-95\%) was maintained by manually spraying water in every $12 \mathrm{~h}$. Samples $(20 \mathrm{~g}$ each of fermented solids) were collected at every $12 \mathrm{~h}$ and they were processed as mentioned above.

\section{Optimization of Spent yeast inoculum for SSF}

In $100 \mathrm{~g}$ of fresh pressmud, different amounts of spent yeast, from $10 \mathrm{~g}-100 \mathrm{~g}$ were mixed along with nutrients in $25 \mathrm{ml}$ of tap water. They were mixed well and spread like beds on stainless steel trays. SSF carried out as mentioned above.

\section{Optimization of inoculum composition i.e. ratio of Spent yeast and culture yeast}

For every $100 \mathrm{~g}$ of fresh pressmud 20\% of inoculum was mixed with nutrients in $25 \mathrm{ml}$ of tap water. Inocula contained different ratio of spent yeast and culture yeast (1:9, 3:7, 5:5, 7:3 and 9:1). SSF carried out as explained above.

\section{Determination of residual Invertase activity and enzyme concentration}

Crude invertase activity of the samples was estimated as per the method described earlier by Bernfeld (1955). One unit of enzyme activity corresponds to the release of $1 \mu \mathrm{M}$ of glucose in one minute, by $1 \mathrm{~mL}$ of enzyme under the assay conditions.

\section{Estimation of protein in Solid state fermentation leachate}

The protein content of lechate samples was quantified spectrophotometrically at $595 \mathrm{~nm}$ according to Bradford (1976) method for all samples using bovine serum albumin as standard.

\section{Characterization of crude invertase Optimum $\mathrm{pH}$ determination}

In order to determine the optimum $\mathrm{pH}$ of the crude enzyme preparation from SSF, $0.2 \mathrm{M}$ Glycine- $\mathrm{HCl}, 0.2 \mathrm{M}$ Acetate, 0.2 M Sodium phosphate and $0.2 \mathrm{M}$ Tris- $\mathrm{HCl}$ buffers were used in the $\mathrm{pH}$ range of 3.0, 4.0-5.0, 6.0-8.0 and 9.0 respectively. All the assays were done at a constant temperature of $35^{\circ} \mathrm{C}$.

\section{Optimum temperature determination}

For determination of the optimum temperature, enzyme activity was assayed at different temperatures in the range from $10^{\circ} \mathrm{C}$ to $60^{\circ} \mathrm{C}$. The desired temperature was provided by using a water bath. The enzyme assays were carried out using $50 \mathrm{mM}$ acetate buffer ( $\mathrm{pH} 4.7)$.

\section{Impacts of metal ions and detergents}

To determine the effects of metal ions on the crude invertase obtained as SSF leachate, $5 \mathrm{mM}$ concentrations of the following metal ions- $\mathrm{Al}^{+3}, \mathrm{Ca}^{+2}, \mathrm{Cu}^{+2}, \mathrm{Fe}^{+3}, \mathrm{Mg}^{+2}$, $\mathrm{Mn}^{+2} \& \mathrm{Zn}^{+2}$ and detergents - SDS and TritonX-100 were

Table 6 Production of invertase by SSF with different components

\begin{tabular}{lccll}
\hline Tray No. & Pressmud, & Water, $\mathbf{~ L ~}$ & Nutrient $\mathbf{m i x}$ & Inoculum (w/w) \\
\hline 1 & 100 & 25 & Added & No inoculum \\
\hline 3 & 100 & 25 & Added & $10 \%$ spent yeast \\
\hline 4 & 100 & 25 & Added & $10 \%$ culture yeast \\
\hline 5 & 100 & 25 & Added & $5 \%$ spent yeast and $5 \%$ culture yeast \\
\hline
\end{tabular}


added into the reaction mixture separately. The enzyme activities were measured; a test sample in the absence of metal ions was used as control.

\section{Purification of crude invertase by Three Phase Partition method (TPP)}

TPP method as reported earlier by Akardere et al. (2010) was used for the partial purification of the crude enzyme sample.

\section{Competing interests}

The authors declare that they have no competing interests.

\section{Authors' contributions}

BK conceived the format of the study and gave the design and coordination for study. BK was responsible analysis and interpretation of data and giving final approval to the version to be published. RK carried out the bioprocess, optimised process parameters, involved in analysing and interpretation of data. RK also took part in quality assessment and pre-treatment of industrial by-products used in this study. RK carried out bio chemical assays in this study and responsible for preparation of initial draft. All authors read and approved the final manuscript.

\section{Acknowledgements}

The authors thank the Management of BIT for giving the opportunity and lab facilities to perform this study. MSME, Gol grant for the incubation activity in Invertase at BIT-TBI (a joint venture of DST, New Delhi and BIT, Sathyamangalam) needs a special mention here.

\section{Received: 19 October 2012 Accepted: 18 December 2012}

Published: 28 December 2012

\section{References}

Akardere E, Ozer B, Celem EB, Onal S (2010) Three-phase partitioning of invertase from Baker's yeast. Sep Purif Technol 72:335-339

Alegre ACP, Polizeli MLTM, Terenzi HF, Jorge JA, Guimaraes LHS (2009) Production Of thermostable invertases by Aspergillus caespitosus under submerged or solid state fermentation using agro-industrial residues as carbon source. Braz J Microbiol 40:612-622

Andjelkovic U, Picuric S, Vujcic Z (2010) Purification and characterization of Saccharomyces cerevisiae external invertase isoforms. Food Chem 120:799-804

Aranda C, Robledo A, Loera O, Contreras-Esquivel JC, Rodrigues R, Aguilar CN (2006) Fungal invertase expression in solid-statefermentation. Food Technol Biotechnol 44:2, 229-233

Arica MY, Senel S, Alaeddinoglu NG, Patir S, Denizli A (2000) Invertase immobilized on spacer-arm attached poly (hydroxyethyl methacrylate) membrane: preparation and properties. J Appl Polymer Sci 75:1685-1692

Ashokkumar B, Kayalvizhi N, Gunasekaran P (2001) Optimization of media for $\beta$ fructofuranosidase production by Aspergillus niger in submerged and solid state fermentation. Process Biochem 37:331-338

Bayramoglu G, Akgol S, Bulut A, Denizli A, Arica MY (2003) Covalent immobilization of invertase onto a reactive filmcomposed of 2-hydroxyethyl methacrylate and glycidylmethacrylate: properties and application in a continuous flow system. Biochem Eng J 14:117-126

Belcarz A, Ginalska G, LobarzewskiJ PC (2002) The novel non-glycosylated invertase from Candida utilis(the properties and the conditions of production and purification). Biochim Biophys Acta 1594:40-53

Bernfeld P (1955) Amylases alpha and beta. Methods Enzymol 1:149-158

Bradford MM (1976) A rapid and sensitive method for the quantitation of microgram quantities of protein utilizing the principle of protein-dye binding. Anal Biochem 72:248-254

Dahot MU, Noomrio MH (1996) Purification and some properties of invertases from Achras sapota fruit. J Islamic Acad Sci 2(2):31-36

Ghosh K, Dahr A, Samanta TB (2001) Purification and characterization of an invertase produced by Aspergillus ochraceus TS. Indian J Biochem Biophys 38:180-185

Guimaraes LHS, Terenzi HF, Polizeli MLT, Jorge JA (2007) Enzyme MicrobTechnol 42:52-57
Guimaraes LHS, Somera AF, Terenzi HF, Polizeli MLTM (2009) Production of B-fructofuranosidases. J A Jorge Process Biochem 44:237-241

Hussain A, Rashid MH, Perveen R, Ashraf M (2009) Purification, kinetic and thermodynamic characterization of soluble acid invertase from sugarcane (Saccarumofficinarum). Plant PhysiolBiochem 47:188-194

Jegou S, Conreux A, Villaume S, Hovasse A, Schaeffer C, Cilindre C, Dorsselaer AV, Jeandet $P$ (2009) One step purification of the grape vacuolar invertase. Anal ChimActa 638:75-78

Kern G, Schülke N, Schmid FX, Jaenicke R (1992) Stability, quaternary structure, and folding of internal, external, and core-glycosylated invertase from yeast. Protein Sci 1:120-131

Lekha PK, Lonsane BK (1994) Comparative titres, location and properties of tannin acyl hydrolase produced by Aspergillus niger PKL 104 in solid-state, liquid surface and submerged fermentations. Process Biochem 29:497-503

Liu CC, Huang LC, Chang CT, Sung HY (2006) Purification and characterization of soluble invertases from suspension-cultured bamboo (Bambusaedulis) cells. Food Chem 96:621-631

Lonsane BK, Ghildyal NP (1992) In: Doelle HW, Mitchell DA, Rolz CE (eds) Solid substrate cultivation. Elsevier Science Publishers Ltd, London, pp 191-209

Mamma D, Kourtoglou E, Christakopoulos P (2008) Fungal multi enzyme production on industrial by-products of the citrus-processing industry. Bioresour Technol 99:2373-2383

Mitchell DA, Lonsane BK (1992) In: Doelle HW, Mitchell DA, Rolz CE (eds) Solid substrate cultivation. Elsevier Science Publishers Ltd, London, pp 1-16

Nguyen QD, Rezessy-Szabo JM, Bhat MK, Hoschke A (2005) Purification and some properties of $\beta$-fructofuranosidase from Aspergillus niger IMI303386. Process Biochem 40:2461-2466

Ozer B, Akardere E, Celem EB, Onal S (2010) Three-phase partitioning as a rapid and efficient method for purification of invertase from tomato. Biochem Eng J 50:110-115

Park YK, Pastores GM (2003) Process for preparing $\beta$-fructofuranosidase enzyme and a process forproducingfructo-oligosaccharides., US Patent 20030082750

Persike DS, Bonfim TB, Santos MHR, Lyng SMO, Chiarello MD (2002) JD Fontana Biores Tech 82:79-85

Rashad MM, Nooman MU (2008) Isolation and characterization of fungal chitosan using different substrates. Adv Food Sci 30:24-29

Rashad MM, Nooman MU (2009) Production, purification and characterization of extracellular invertase from Saccharomyses cerevisiae NRRL Y-12632 by solid state fermentation of red carrot residue. Aust J Basic Appl Sci 3:3, 1910-1919

Rashad MM, Mahmoud AEE, Desouky MA, Nooman MU (2006) Purification and characterization of extra and intracellular $\beta$-fructofuranosidase from Saccharomyces cerevisiae growing on Eichhorniacrassipes leaf extract. Deutsche Lebensmittel Rundschau 102:157-166

Rubio MC, Runco R, Navarro AR (2002) Invertase from a strain of Rhodotorula glutinis. Phytochemistry 61:605-609

Sangeetha PT, Ramesh MN, Prapulla SG (2005) Recent trends in the microbia production, analysis and application of Fructo oligosaccharides. Trends Food SciTechnol 16:442-457

Sanjay G, Sugunan S (2006) Enhanced pH and thermal stabilities of invertase immobilized on montmorillonite K-10. Food Chem 94:573-579

Sharma A, Gupta MN (2001) Purification of pectinases by three-phase partitioning. Biotechnol Lett 23:1625-1627

Sirisansaneeyakul S, Jitbanjongkit S, Prasomsart N, Luangpituksa P (2000) Production of fructofuranosidase from Aspergillus niger ATCC20611. Kasetsart J 34:378-386

Uma C, Gomathi D, Muthulakshmi C, Gopalakrishnan VK (2010) Production, purification and characterization of invertase by Aspergillus flavus using fruit peel waste as substrate. Adv Biol Res 4(1):31-36

Vitolo M, Duranti MA, Pellegrim MB (1995) Effect of $\mathrm{pH}$, aeration and sucrose feeding on invertase activity of intact Saccharomyces cerevisiae cells grown in sugarcane black strap molasses. J Ind Microbiol 15:75-79

doi:10.1186/2193-1801-1-81

Cite this article as: Kumar and Kesavapillai: Stimulation of extracellular invertase production from spent yeast when sugarcane pressmud used as substrate through solid state fermentation. SpringerPlus 2012 1:81. 